\title{
TYPIFICATION OF ASTER ALPINUS VAR. GLABRATUS (ASTERACEAE)
}

\author{
Zbigniew SZelĄG ${ }^{1} \&$ YURIY Kobiv
}

\begin{abstract}
Zbigniew Szelag, Pedagogical University of Cracow, Department of Botany, Podchorązych 2, 30-084 Kraków, Poland; e-mail: azszelag@wp.pl

Yuriy Kobiv, Institute of Ecology of the Carpathians, National Academy of Sciences of Ukraine, Kozelnytska Str. 4, 79026 Lviv, Ukraine; e-mail: ykobiv@gmail.com
\end{abstract}

The name Aster alpinus var. glabratus Herbich was first published by Herbich (1834: 574) and linked with the description in Additamentum ad floram Galiciae (Herbich 1831: 44). The name was based on specimens he collected in the Pieniny Mountains, Western Carpathians, Poland. Aster alpinus var. glabratus is distinguished by its glabrous leaves which are ciliate at the margins, and involucral bracts (in the protologue inappropriately named 'squamae calycinae'), as opposed to the nominal taxon with hairy (at least adaxially) laminae. Aster alpinus var. glabratus is widely distributed in the Western Carpathians (Poland, Slovakia) and Eastern Carpathians (Romania, Ukraine).

Franz Herbich (1791-1865) visited the Pieniny Mountains in 1829, 1830 and 1832 (Herbich 1834: 564, 572). All the taxa from the Pieniny Mountains enumerated in his Additamentum were collected in 1829 (Herbich 1831: 6).

Continuing a revision of Herbich's collection, we found in the herbarium of the Ivan Franko National University of Lviv (LW) eight specimens collected by him in the Pieniny Mountains. Only two of them (LW 214582, LW 214579) come from 1829. Specimen LW 214582 is labelled A. alpinus without any intraspecific attributes. Specimen LW 214579 contains two labels with different names: $A$. alpinus var. glabriuscul $[u s]$ and $A$. alpinus var. pienninus, which, however,

\footnotetext{
1 Corresponding author
}

were never published. Remarks on the second of them conform to the diagnosis of $A$. alpinus var. glabratus stated in the protologue. Here we designate this specimen as the lectotype of the name A. alpinus var. glabratus (Fig. 1).

On the herbarium sheet of LW 214577 the collecting date was given as '1829-1830-1832'; that is, the label includes all the years during which Herbich visited the Pieniny Mountains (Herbich 1834). The morphological characters of all the mentioned specimens suit the description of $A$. alpinus var. glabratus.

The present paper is the latest in a series on the typification of the vascular plant taxa described from Poland (Cieślak \& Paul 2011; Szeląg 2013; Szeląg \& Kobiv 2014, 2016).

Aster alpinus var. glabratus Herbich Fig. 1

Addit. ad Fl. Galic.: 43. 1831 \& Flora 17: 574. 1834. - A. alpinus subsp. glabratus (Herbich) Dostál, Folia Mus. Rerum Nat. Bohemiae Occid., Bot. 21: 12. 1984. - TyPe Locality: 'In montibus Pienninis'. - LeCtotype (designated here): [Poland] In Carpatis Circuli Sandeciensis prope Acidulas Szczawnicensis in montibus Piennini, August 1829, F. Herbich (LW 214579).

Notes. We also happened to get access to a copy of Additamentum ad floram Galiciae (Herbich 1831), in which textual contents from pages 43 and 44 had been swapped, so that the description of Aster alpinus var. glabratus is located on page 44 (at species no. 67) instead of page 43 


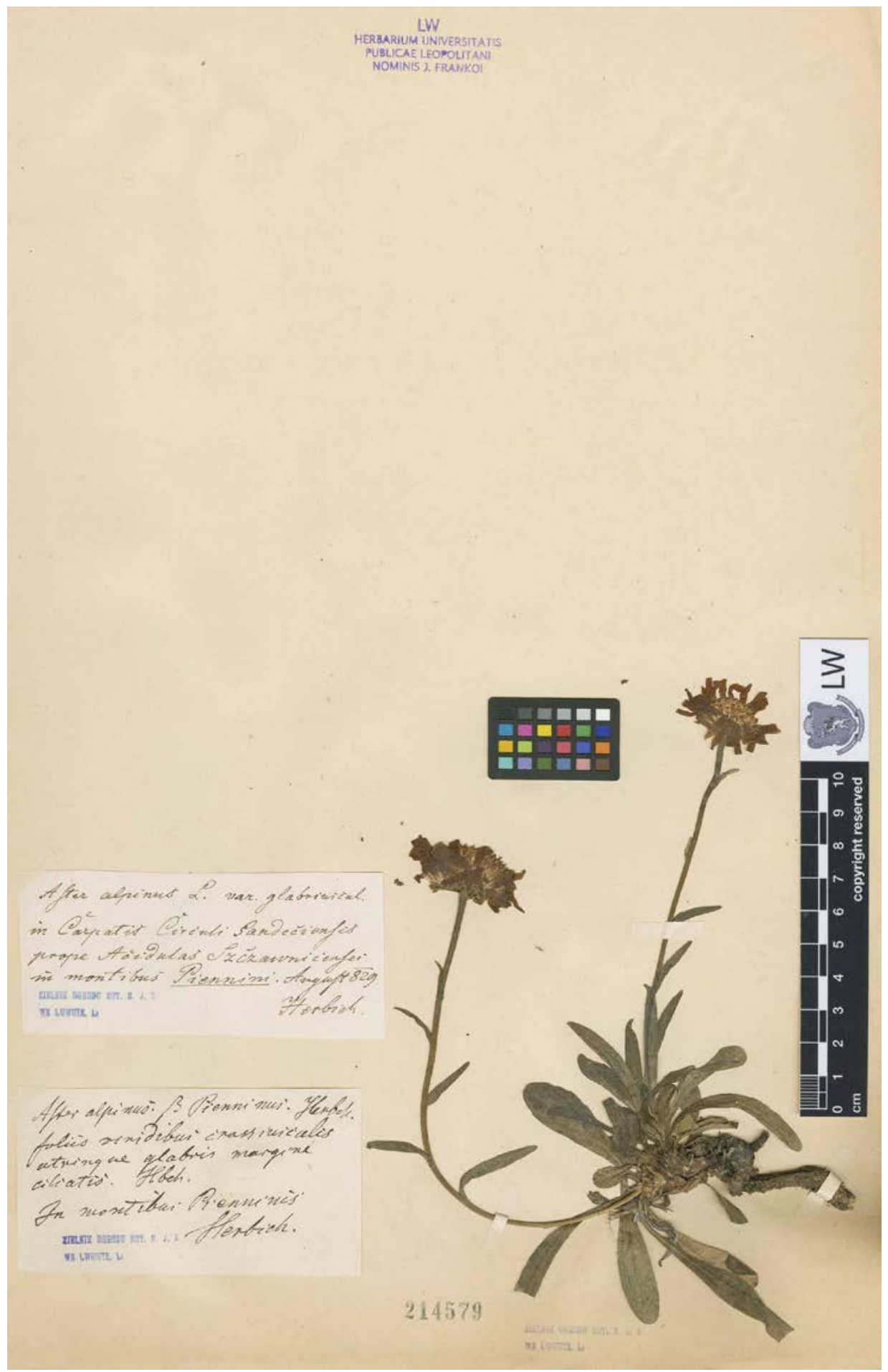

Fig. 1. Lectotype of Aster alpinus var. glabratus Herbich (LW 214579). 
(at species no. 64). It is evidently a misprint, because the book's table of contents indicates page 43 for the description of this taxon.

OTHER HISTORICAL MATERIAL: [Poland] In Carpatis Circuli Sandeciensis prope Acidulas Szczawnicenses in montibus Piennini in jugo montis St. Kunigunde etiam Kronenberg [...], Galicia, August 1829-1830-1832, F. Herbich (LW 214577); In montibus Pienninis Circuli Sandeciensis, Galicia, 1832, F. Herbich (LW 214578); In montibus Pienninis Circuli Sandeciensis, Galicia, mense Augusto 1832, F. Herbich (LW 214580); In cacumine montium Pienninorum Circuli Sandeciensis, Galicia, mense Augusto 1832 F. Herbich (LW 214581); Im Pieninen Gebirge, Galizien, Sandecer Kreiß, Juli 1829, F. Herbich (LW 214582); Im Pieninen Gebirge im Sandecier Kreiß, F. Herbich (LW 214661); In rupibus calcareis montium Pienninorum Circuli Sandeciensis (Galicia) incipit 1650 pedes supra mare ad ripas fluvii Dunajec et adscendit ad cacumina [...] 3400 pedes s.m., F. Herbich (LW 214662).

AcKnowledgements. We are grateful to Tetiana Khmil (Curator of LW) for making the relevant collections available for study and for providing excellent scanned images of Herbich's specimens, and to the anonymous reviewer for helpful suggestions and corrections.

\section{REFERENCES}

Cieślak E. \& Paul W. 2011. Typification of Carlina acanthifolia var. spathulata (Asteraceae) and new authorship for C. onopordifolia. Polish Bot. J. 56: 55-60.

Herbich F. 1831. Additamentum ad floram Galiciae. Kuhn et Millikowski, Leopoli, Stanislavoviae et Tarnoviae et C. Wenzel, Przemysliae.

Herbich F. 1834. Botanischer Ausflug in die galizisch-karpatischen Alpen des Sandezer Kreises. Flora 17: 561-575.

SzELĄG Z. 2013. History of discovery and typification of $G a-$ lium cracoviense (Rubiaceae). Polish Bot. J. 58: 363-365.

SzelĄG Z. \& KobIV Y. 2014. Typification of Chrysanthemum zawadzkii (Asteraceae). Polish Bot. J. 59: 27-30.

SzelĄG Z. \& KoBIV Y. 2016. Typification of Senecio carpathicus (Asteraceae). Polish Bot. J. 61: 187-188. 